Available online at GSC Online Press Directory

GSC Biological and Pharmaceutical Sciences

e-ISSN: 2581-3250, CODEN (USA): GBPSC2

Journal homepage: https://www.gsconlinepress.com/journals/gscbps

(RESEARCH ARTICLE)

\title{
Variation studies of morphological characters of cashew trees (Anacardium occidentale) on Kogi State University Campus, Anyigba, Kogi State, Nigeria
}

\author{
Ehoniyotan Olayemi Ibukun * and Udo Eno-Obong Jackson \\ Department of Plant Science and Biotechnology, Kogi State University, Anyigba, Kogi State, Nigeria.
}

Publication history: Received on 26 August 2019; revised on 10 September 2019; accepted on 12 September 2019

Article DOI: https://doi.org/10.30574/gscbps.2019.8.3.0161

\begin{abstract}
Variability could exist in a typical cashew field for most morphological characters and such morphological characters have been used as a powerful tool in the classification of cultivars and as such morphological traits continue to be the first step in the studies of genetic relationships. In this research work using morphological traits effort was made to access the variations among sixty (60) randomly selected trees from different locations across Kogi State University campus, from Faculties of Management Sciences, Natural sciences, Social sciences, Law, Agriculture and the Botanical garden. Morphological characters from Cashew descriptors by International Board for plant Genetic Resources (IBPGR) were used to determine the variations among the trees. Results indicate variations among trees on the campus, the dominant fruit shape observed was conical-obovate, the dominant fruit colour observed was yellow with a high percentage (71.67\%), the dominant nut weight was intermediate (5-6 g), the dominant shape of leaves in the sampled population is obovate with $43.33 \%$, the dominant leaf apex shape was rounded with $41.6 \%$. The tree habit is quite variable with upright and open habit having 50\% while upright and compact habit have the least $15 \%$. Three cashew descriptors were not observed in the trees on campus which are very low nut weight, cylindrical apple shape and pointed leaf apex shape. Variations were also observed in fruiting time, flower colours. Variation could be attributed to genetic history, though molecular studies would be needed to ascertain the genetic nature of observed variations.
\end{abstract}

Keywords: Variation; Morphological; Character; Genetic; Dominant

\section{Introduction}

Cashew (Anacardium occidentale L.) is a tropical nut tree likely native of South America, with Central Brazil agreed to be the centre of origin [1]. After the introduction of cashew crop to Asia and Africa during the explorations of European conquerors, mainly Portuguese in the 16th century to prevent soil erosion cashew has widely spread becoming a major export commodity crop for several countries [2]. In 2011, about 4.7 million tons of raw nuts were produced worldwide, almost equally distributed between Asia and Africa. The growing interest in cashew crop is shown by the evidence of cashew kernel, the main cashew product holding a steady growing production volumes and sales over the last 20 years [3]. Today, cashew cultivation has spread to almost all the states of Nigeria with increased processing, shipping and exporting activities. The major Cashew growing areas in different parts of Nigeria in the order of the level of productivity with respect to the different regions of the country are: Enugu, Abia, Imo, Anambra, Ebonyi and Cross River States in the east and southern part, Oyo, Osun, Ondo, Ekiti and Ogun States in the western part, Kwara, Kogi, Nassarawa, Benue, Taraba, Niger, Federal Capital Territory (Abuja), Kaduna and Plateau in the Middle Belt and; Sokoto and Kebbi States in the North-western of the country [4]. Cashew nut tree provides food, employment, income and the wood is used for carpentry mainly in the construction of boats and ferries while other products derived from it include firewood and charcoal [5].

\footnotetext{
${ }^{*}$ Corresponding author

E-mail address: ehoniyotanoi@ksu.edu.ng
} 
Breeding of cashew is mostly based on the selection of useful phenotypic and agronomic traits such as nut size, nut weight, colour of apple, size of the fruit, tree canopy, length of panicle and overall yield production [6]. Traditionally, genetic diversity evaluated in crop species is based on differences in morphological characters and qualitative trait [7]. In many cases, morphological character has been used as a powerful tool in the classification of cultivars and as such morphological trait continue to be the first step in the studies of genetic relationship in most breeding programmes [8]. Thus, this study was carried out to observe the Morphological Variations among trees growing on Kogi State University Campus, Anyigba.

\section{Material and methods}

\subsection{Study area and map}

The study was conducted from $8^{\text {th }}$ November, 2018 to $21^{\text {st }}$ January, 2019 within Kogi State University Campus, Anyigba. The study area is located on latitude $7^{049} \mathrm{E}$ and longitude 7018E. Anyigba is located at Eastern part of Kogi State in Dekina local government area. Anyigba lies between latitude 7015-7029 N and longitude $7^{0} 11-7^{0} 32 \mathrm{~N}$ and with average altitude of 420 meters above sea level. The study area falls within the tropical wet and dry climate region and the guinea savanna, with mean annual temperature of $25^{\circ} \mathrm{C}$ and rainfall $1600 \mathrm{~mm}$.

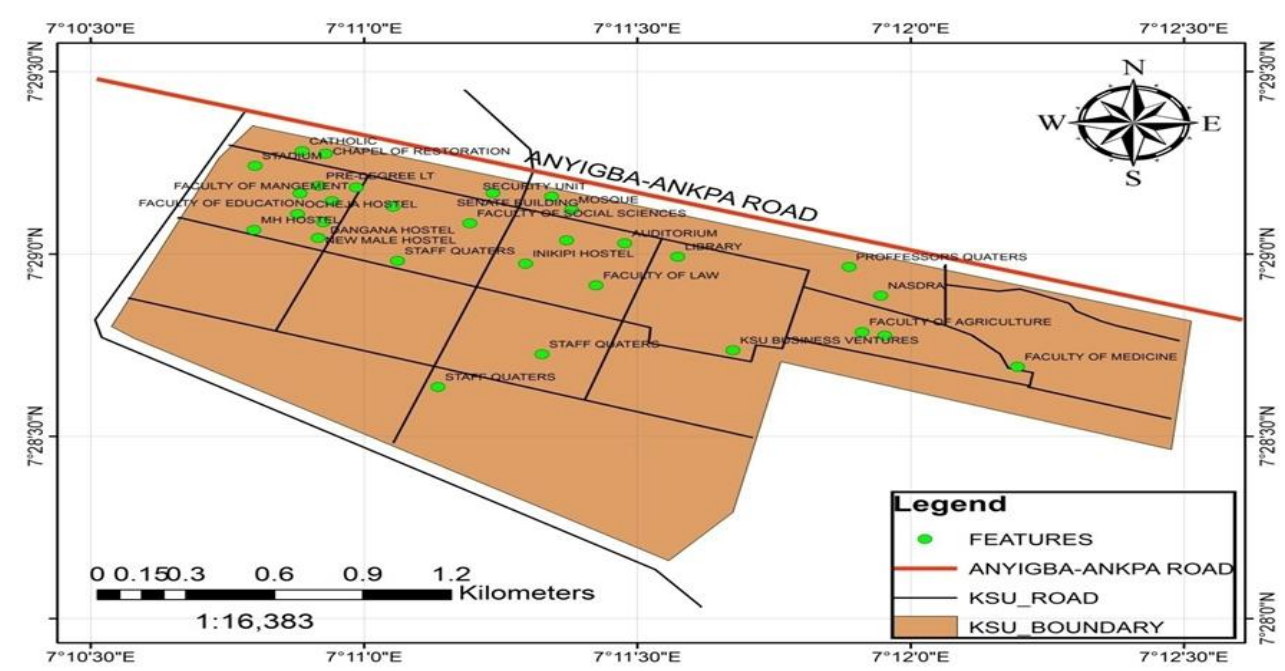

Figure 1 Map of Kogi State University, Anyigba. Source: Department of Geography, KSU, Anyigba

\subsection{Material used}

Weighing balance, tags, nail, hammer, marker, nylon bag and paper

\subsection{Method}

Sixty (60) randomly selected trees of Anacardium occidentale were tagged with alphabets A1-A60.

\subsection{Data collection}

Data were collected from the tagged trees from flowering to end of fruiting stage. The following data were collected.

\subsubsection{Cashew apple colour}

For all the randomly selected trees of Anacardium occidentale, the dominant apple colour of each tree was recorded.

\subsubsection{Cashew apple shape}

For all the sixty selected trees on the campus, fruits were observed for shapes by comparing with shapes in cashew descriptors by [9]. 


\subsubsection{Nut weight}

6-8 nuts from each randomly selected tree were collected separately in nylon bags labeled according to the trees tags for easy identification of their nuts, the nut weights were taken using an electronic weighing balance. The value read on the weighing balance was divided by the number of nuts in the scale to record the average weight.

\subsubsection{Leaf shape}

The leaf shape of each tree was identified by comparing with leaf shapes in Cashew descriptor by [9].

\subsubsection{Leaf apex shape}

The leaves collected from each tree were compared to the leaf apex shapes in cashew descriptors by [9] to determine the leaf apex shape of the selected trees.

\subsubsection{Tree habit:}

The tree habits were identified by comparing each tree with the habit in Cashew descriptors by [9].

\section{Results and discussion}

\subsection{Cashew apple colour}

Result of cashew apple colour presented in figure 1 indicates variation in cashew apple colour of cashew trees on the University Campus. The colours (Red, Yellow, and Red/Yellow) were observed with trees producing yellow cashew apple having the highest presence (71.67\%). 15\% of the trees produced Red Cashew apples while $13.33 \%$ of the trees produced a mixture of Red and Yellow cashew apples. The trees producing Yellow colour maybe due to selection/propagation of yellow producing seeds over the red producing seeds. Nayak et.al [10] reported Yellow apple colour to be higher in India germplasm collection.

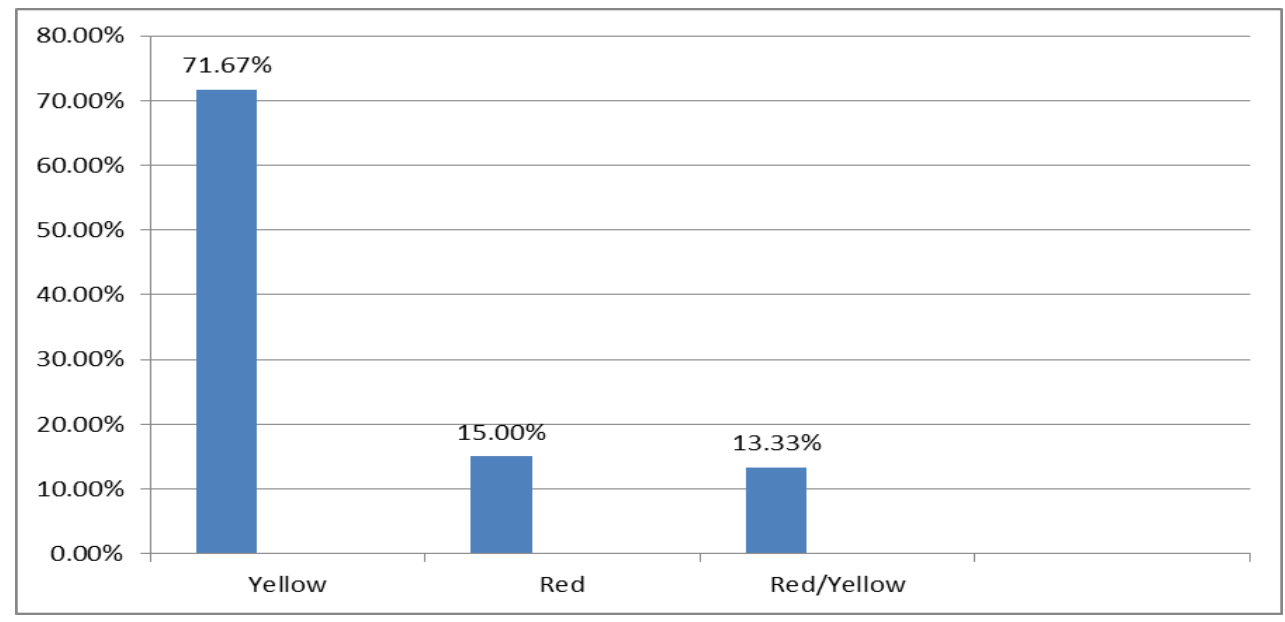

Figure 1 Percentages of observed cashew apple colours of the selected trees

\subsection{Cashew apple shape}

Result of cashew apple shape (figure 2) reveals the variation in apple shape in cashew trees on the Campus. $90 \%$ of the selected trees produced apple with conical-obovate shape, while $6.67 \%$ of the trees produced round apples and $3.33 \%$ produce pyriform. None of the trees produce apple that are cylindrical. In a report by Nayak et al [10] pyriform was the least present apple shape and happens to be the least observed among cashew trees on the campus, though cylindrical apple shape was totally absent. 


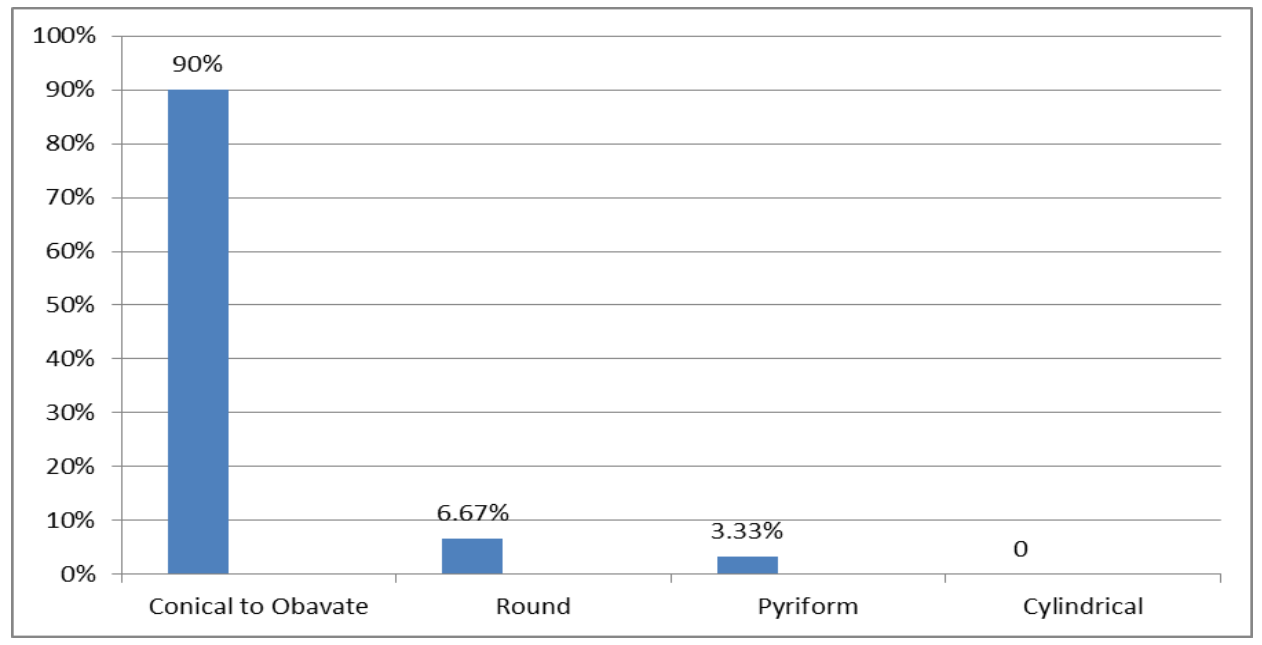

Figure 2 Percentages of observed cashew apple shapes of the selected trees

\subsection{Cashew nuts weight}

The result of cashew nut weight presented in figure 3 reveals the absence of nuts with very low weight $(>1 \mathrm{~g})$. The trees produced varying grades of nut weights; very high (>9 g), high (7-8 g), intermediate (5-6 g), Low (3-4 g). 60\% of the trees produced intermediate nut weight, $20 \%$ of the trees produced high nut weight, $15 \%$ produced low nut weight and $5 \%$ produced very high nut weight. There are reports of varying nut weight in cashew germplasm.

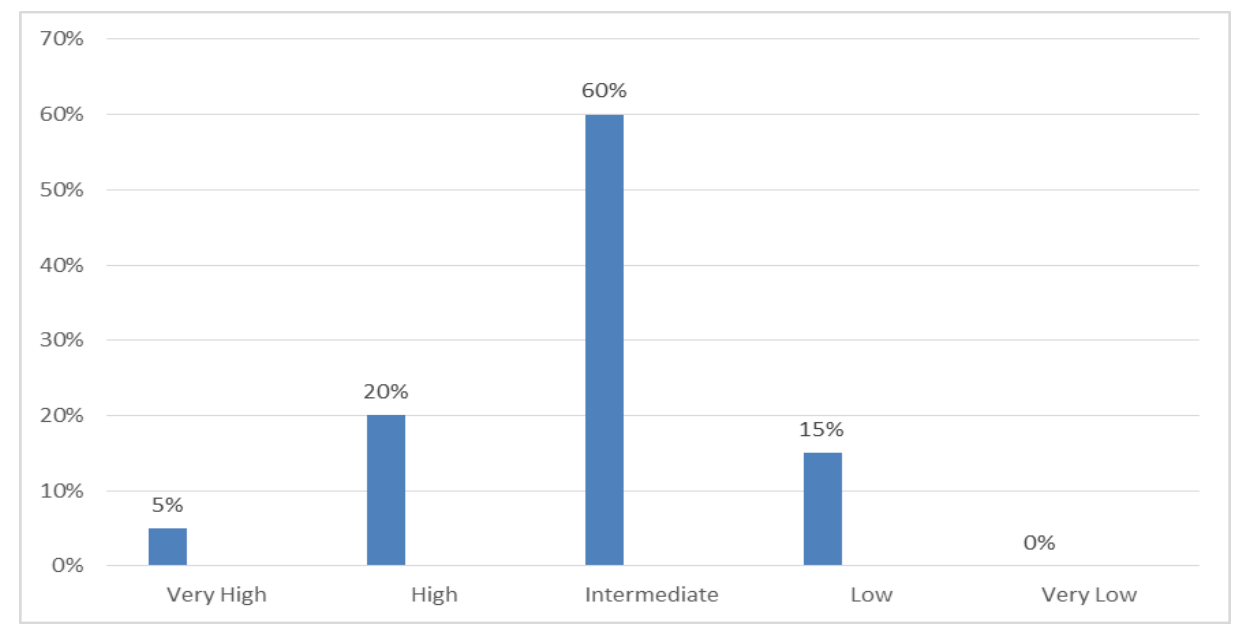

Figure 3 Percentages of cashew nuts weights (g) of the selected trees

\subsection{Cashew leaf shapes, leaf apex shapes and tree habits}

The four leaf shapes in Cashew descriptors by IBPGR were observed in cashew trees on the campus. As presented in figure 4 result reveals $4.33 \%$ of the trees had obovate leaf shape, $26 \%$ had oblong leaf shape, $20 \%$ had ovate while $10 \%$ had circular leaf shape. Figure 5 also reveals variations in leaf apex shape though, the pointed leaf apex shape was not observed on the trees studied. The pointed leaf shape seems to be rare among Cashew trees as Nayak et al [10] reported the leaf apex shape to have occurred in just 7 accessions of all the 115 accessions studied. The rounded leaf apex shape was observed in $66.6 \%$ of the trees, indented leaf apex shape was observed in $33.4 \%$ of the trees. The shape of leaf among is used as an important basis for classification [11]. The tree habits described in Cashew descriptors were all observed in Cashew trees on the campus as presented in figure 6. The highest percentage was upright and open with $50 \%$ of the trees having this habit the least was upright and compact with $15 \%$ while spreading occurred in $35 \%$ of the trees. In a research work by [12], they reported that $60 \%$ of $A$. occidentale accessions had upright/open tree shape. 


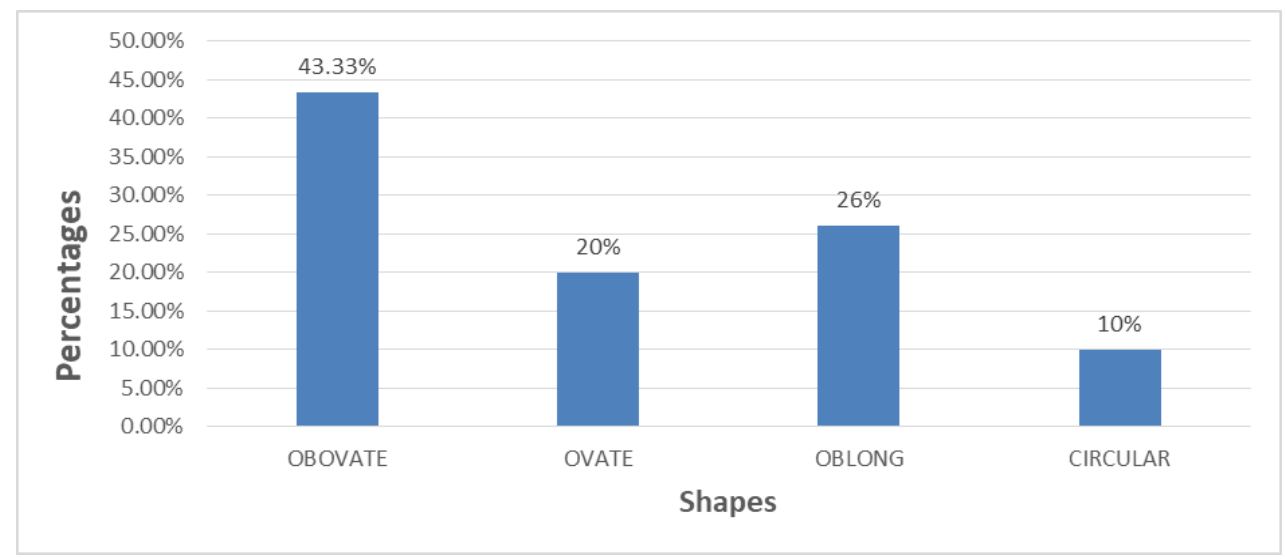

Figure 4 Percentages of leaf shapes observed from the selected trees

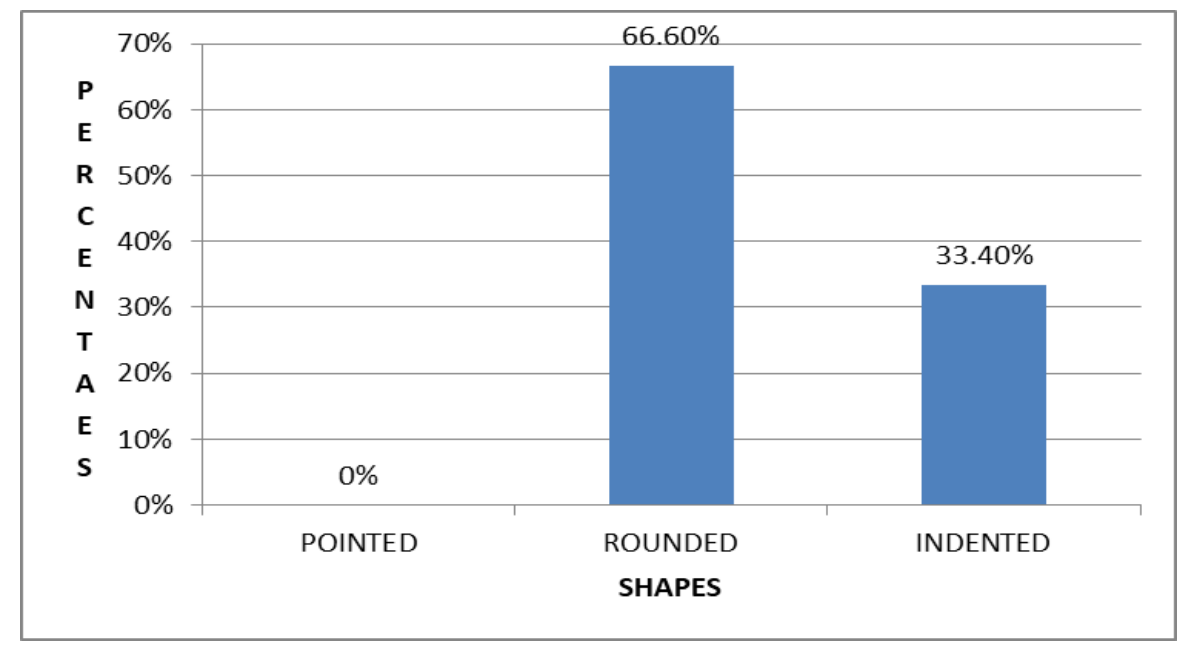

Figure 5 Percentages of leaf apex shapes observed in the selected trees

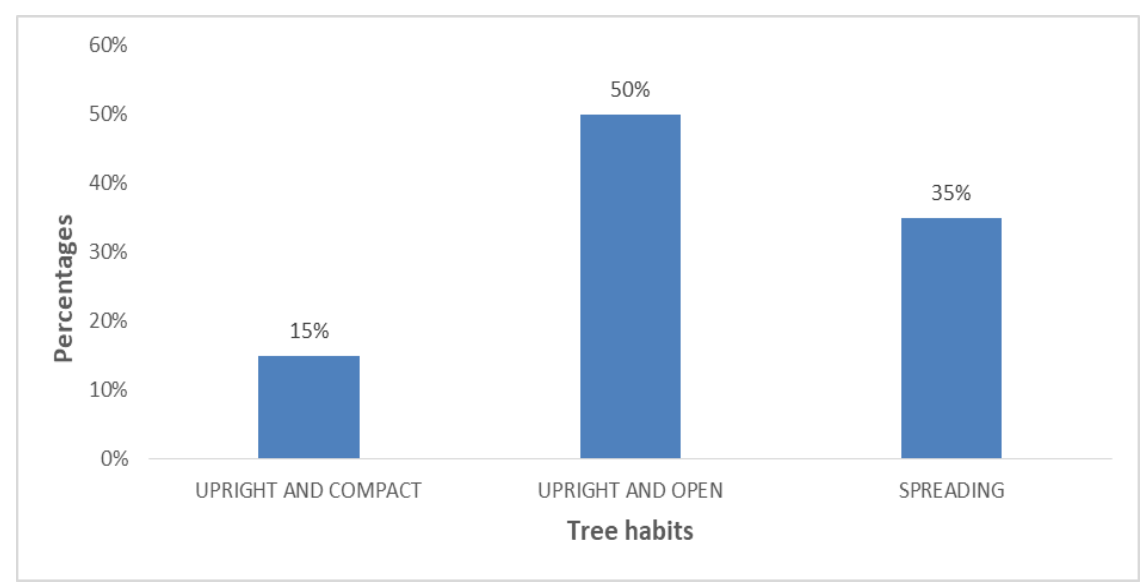

Figure 6 Percentages of tree habits observed in the selected trees

\section{Conclusion}

The cashew trees on Kogi State University Anyigba Campus show variations in characters studied. Majority of the trees produced yellow apples that are more accepted locally and said to be juicy and sweet. Variations were observed in apple colours, apple shape and nut weight. Obovate leaf shape is the most common types among all the trees, pointed leaf apex shape is the most common type among all the trees while upright and open tree habit is the most 
common type of tree habit present in the trees. However, to confirm whether the variations are genetic in nature there is need for characterization using molecular markers.

\section{Compliance with ethical standards}

\section{Acknowledgments}

We sincerely appreciate the staff of the department of Plant science and Biotechnology and security unit for the assistance rendered.

\section{Disclosure of conflict of interest}

There is no conflict of interest.

\section{References}

[1] Nair KP. (2010). The agronomy and economy of important tree crops of the developing world. Access Online via Elsevier. .

[2] Jaeger P. (1999). The Market for Cashew Nuts and its Relevance to African Production, (October).

[3] Azam-Ali SH and Judge EC. (2001). Small-scale cashew nut processing. Rugby, UK: Food and Agriculture organization - FAO.

[4] Reddy L, Mohammed MG and Kumar PB. (2002). Evaluation of high yielding clones under Bapatla conditions for nut yield and other characters. The Cashew, 16(4), 26-31.

[5] Akinwale TO. (2000). Cashew apple juice: Its use in fortifying the nutritional quality of some tropical fruits. European Food Research Technology, 211, 205-207.

[6] Mneney EE, Mantell SH and Mark B. (2001). Use of random amplified polymorphic DNA (RAPD) markers to reveal genetic diversity within and between populations of cashew (Anacardium occidentale L.). Journal of Horticultural Science and Biotechnology, 76, 375 - 383.

[7] Schut JW, X QI and Stam P. (1997). Association between relationship measures based on AFLP markers, pedigree data and morphological traits in barley. Theoretical and Applied Genetics, 95, 1161- 1168.

[8] Van Beuningen LT and Busch RH. (1997). Genetic diversity among North American spring wheat cultivars. In: Analysis of the coefficient of parentage matrix. Crop Science, 37, 564-573.

[9] IBPGR. (1986). Cashew Descriptor List International Bureau of Plant Genetic Resources, Rome.

[10] Nayak MG, Mohana GS, Bhat PS, Sacos PL, Swamy KRM and Bhat MG. (2014). Minimum descriptor of Cashew germplasm accessions. ICAR- Directorate of Cashew Research Puttur 574 202, D.K., Karnataka, India.

[11] Methela NJ, Faruk O, Islam MS and Hossain MM. (2019). Morphological Characterization of Guava Germplasm (Psidium sp.). Journal of Bioscience and Agriculture Research, 20(01), 1671-1680.

[12] Castro ACR, Sobreira - Junior OV, Bordallo PN, Oliverira KGS and Bezerra CF. (2011). Morphological variability of Cashew from the Brazillian Savannah. Acta Horticulturae, 918, 863-869.

\section{How to cite this article}

Ehoniyotan OI and Udo EJ. (2019). Variation studies of morphological characters of cashew trees (Anacardium occidentale) on Kogi State University campus, Anyigba, Kogi State, Nigeria. GSC Biological and Pharmaceutical Sciences, 8(3), 17-22. 